\title{
Postmonorchis sp. inq. (Digenea: Monorchiidae) metacercariae infecting natural beds of wedge clam Donax trunculus in Italy
}

\author{
F. Carella ${ }^{1, *}$, J. Culurgioni ${ }^{2}$, S. Aceto ${ }^{1}$, G. Fichi ${ }^{3}$, T. Pretto ${ }^{4}$, D. Luise ${ }^{1}$, A. Gustinelli ${ }^{5}$, \\ G. De Vico ${ }^{1}$ \\ ${ }^{1}$ Department of Biology, University of Naples Federico II, 80134 Napoli, Italy \\ ${ }^{2}$ Department of Life and Environmental Sciences, University of Cagliari, 09126 Cagliari, Italy \\ ${ }^{3}$ Laboratory of Ichthyopathology, Experimental Zooprophylactic Institute of Lazio and Tuscany, 56123 Pisa, Italy \\ ${ }^{4}$ Experimental Zooprophylactic Institute of Venice, 35020 Legnaro, Padua, Italy \\ ${ }^{5}$ Department of Veterinary Public Health and Animal Pathology, University of Bologna, 40064 Ozzano dell' Emilia, Italy
}

\begin{abstract}
The wedge clam Donax trunculus Linnaeus, 1758 is one of the most common bivalve molluscs inhabiting the sandy shores of the Mediterranean Sea and is considered an important commercial resource. In this study, we report the first molecular, morphological and histopathological descriptions of metacercariae from a trematode belonging to the genus Postmonorchis (Digenea: Monorchiidae) that infects $D$. trunculus in natural beds of the Italian Tyrrhenian coast (Campania, Lazio and Tuscany). Morphological analysis of the parasite revealed a combination of features that exist in the 3 previously identified species of Postmonorchis, viz. P. donacis, P. variabilis and $P$. orthopristis, with the addition of new, distinctive morphological characteristics. The pathogen exhibited a predilection for the gill; however, it was also present in the labial palp and mantle in addition to the gut, kidney epithelium and foot. The inflammatory response was characterised by either a focal or diffuse haemocyte infiltration followed by the formation of multiple, large multi-layered capsules associated with tissue destruction. The prevalence of the pathogen ranged from 75 to $100 \%$, while the infection intensity fluctuated among the study areas. Further studies regarding the life cycle of this parasite and the identification of other larval and adult stages and their respective hosts may confirm the identification of a new species of Postmonorchis that infects wedge clams in Mediterranean waters. The study of the parasite is completed by molecular analysis of the ITS1 and ITS2 rDNA sequences.
\end{abstract}

KEY WORDS: Donacidae $\cdot$ Bivalvia $\cdot$ Metacercariae $\cdot$ Monorchiidae $\cdot$ Postmonorchis $\cdot$ Trematoda Parasite $\cdot$ Mediterranean $\cdot$ ITS

Resale or republication not permitted without written consent of the publisher

\section{INTRODUCTION}

During the last several years, research regarding bivalve diseases has significantly increased, particularly with respect to the bacterial and protozoan agents in cultured species that are listed by the World Organisation for Animal Health (OIE) (Berthe 2008). Studies of Platyhelminthes have focused primarily on taxonomy and rarely on the lesions that are linked to the host-parasite interaction (Doanh et al. 2007, de Montaudouin et al. 2009).
Trematodes have complex life cycles with asexual forms parasitizing the internal organs of molluscs, whereas the sexual stages occur mainly in vertebrates and only occasionally in invertebrates. Depending on the species, the larvae of most trematodes need a second intermediate host, which may be either an invertebrate or a vertebrate (Cribb et al. 2003, Madhavi 2008).

In the Mediterranean Sea, parasitosis in bivalve molluscs is caused mainly by faustulid, fellodistomid, gymnophallid and bucephalid trematodes (Palombi 
1934, Lauckner 1983, Ramòn et al. 1999, Culurgioni et al. 2006). In contrast, reports on the Monorchiidae family have mostly described species in the Atlantic or Pacific Ocean, where the cercariae develop within sporocysts of bivalve species such as Cumingia tellinoides, Abra ovata, Macoma nasuta (Martin 1940, Maillard 1975, Bartoli 1984) and Donax gouldii (Young 1953, Winter \& Hatch 2010). The only reported case in the Mediterranean Sea is Cerastoderma edule infected by Monorchis parvus (Bartoli et al. 2000).

The wedge clam Donax trunculus is an important marine resource obtained by the exploitation of natural beds, distributed from the Atlantic coast of France to Senegal and the shallow bottoms of the Mediterranean Sea (Gaspar et al. 2002, Manca Zeichen et al. 2002, La Valle 2006). Marketable landings of this bivalve are in the range of 535 to $970 \mathrm{t} \mathrm{yr}^{-1}$ in Europe (Food and Agriculture Organisation of the United Nations - Fisheries Global Information System: www. fao.org), and although fishing has slightly declined in recent years, the wedge clam remains a significant commercial species for Italy. Despite the importance of the wedge clam, little is known about the pathogens and parasites that affect the health of $D$. trunculus populations. Recent studies suggest the use of this species as a bioindicator of physiological and cellular alterations caused by pollution (Fishelson et al. 1999, Yawetz et al. 2010). Moreover, some reports refer to the parasitic castration of $D$. trunculus caused by the faustulid Bacciger bacciger and damage from the gymnophallid Meiogymnophallus strigatus or a Rickettsia-like organism (Comps 1979, Bartoli 1983, Ramòn et al. 1999), with no record of Monorchiidae infections.

In this report, we present the first study of Postmonorchis sp. inq. (Digenea: Monorchidae) metacercariae infecting the wedge clam Donax trunculus along the Italian coast of the Mediterranean Sea. The parasite was detected in the years 2009, 2010 and 2012. After a histopathological study on wedge clams, in order to assess the taxonomic position of the parasite, it was characterised morphologically and analysed at the molecular level by sequencing the internal transcribed spacer regions 1 and 2 of the ribosomal DNA.

\section{MATERIALS AND METHODS}

\section{Sampling}

Donax trunculus specimens were collected during the summer from different geographical areas over a period of several years. The sampling sites in the
Campania region were the mouth of the Volturno River (41 $0^{\circ} 57.24^{\prime \prime} \mathrm{N}$, $\left.13^{\circ} 56^{\prime} 49.56^{\prime \prime} \mathrm{E}\right)$ during July 2009/2010 (20 clams) and Litorale Domizio (41 ${ }^{\circ} 4^{\prime}$ 8.39" N, 1351'3.65" E) during July 2012 (20 clams). In September 2012, samples were collected at Formia $\left(41^{\circ} 14^{\prime} 20.73^{\prime \prime} \mathrm{N}, 13^{\circ} 36^{\prime} 43.42^{\prime \prime} \mathrm{E}\right)$ in the Lazio region (20 clams) and at sites in the Tirrenia locality $\left(10^{\circ} 17^{\prime} 04^{\prime \prime} \mathrm{N}, 43^{\circ} 37^{\prime} 28^{\prime \prime} \mathrm{E}\right)$ in Tuscany (100 clams), while samples were also collected at Feraxi Beach $\left(39^{\circ} 19^{\prime} 07^{\prime \prime} \mathrm{N}, 9^{\circ} 13^{\prime} 19^{\prime} \mathrm{E}\right)$ in eastern Sardinia (30 clams; Fig. 1). The clams were collected from the shore using a hand-held semi-circular dredge as used by the local fishermen. The clams were immediately transferred into 151 of water collected from the sampling location and maintained in a cool environment in an insulated sealed container for transit to the laboratory with a maximum transit time of $2 \mathrm{~h}$. The samples were opened in the laboratory and examined for external signs under a dissecting microscope (Nikon SMZ-10). To obtain a positive identification of the Donax species as the Mediterranean D. trunculus, 5 samples were submitted to expert taxonomists at the Zoological Museum of Naples. The observed metacercarial cysts were scraped off the surface of gills and labial palps, and the wet mounts were examined by light microscopy. The cysts were stored in 70 and $100 \%$ alcohol for morphological identification and further molecular analysis, respectively. Specimens were also deposited in the Scientific Catalogue of the Museum Collection of the Department of Biology, University of Naples Federico II under reference number DBCUnina-Plat00057.

\section{Light microscopy}

The bivalves were fixed in Davidson's fixative for 24 to $48 \mathrm{~h}$ and then processed for routine histopathology. Two transverse sections, approximately $5 \mathrm{~mm}$ thick, including the mantle, gonad, digestive gland, gills, kidney and foot, were excised from each clam and placed into histological cassettes. To obtain a more complete view of the parasitosis, a $5 \mathrm{~mm}$ piece of the gill was also removed from each animal and included with the sample in the longitudinal orientation. The tissue samples were embedded in paraffin wax, sliced in $5 \mu \mathrm{m}$ sections and subsequently stained with haematoxylin and eosin (H\&E). Additional stains, such as PAS-BA and Masson's Trichrome (Mazzi 1977), were also used.

Parasite prevalence, infection intensity and immune response efficiency were also evaluated at the sites of infection, including the gill, mantle and labial palps. 


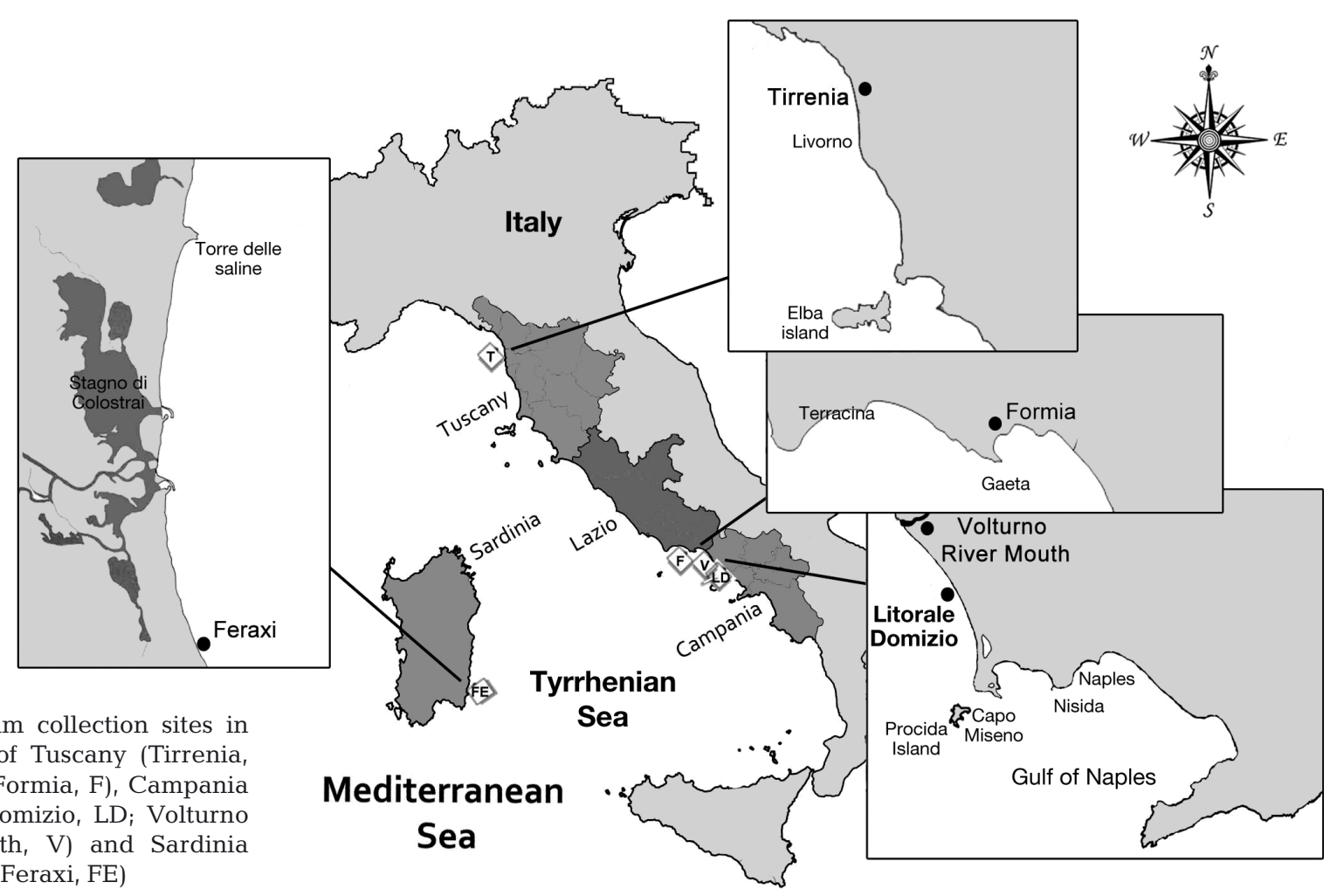

Fig. 1. Clam collection sites in the areas of Tuscany (Tirrenia, T), Lazio (Formia, F), Campania (Litorale Domizio, LD; Volturno River mouth, V) and Sardinia (Feraxi, FE)

For the gill tissues, the data were obtained by histological examination (histological infection density, HID; Bush et al. 1997). In particular, the value of intensity was determined on a fixed area of $8 \mathrm{~mm}^{2}$ in 2 consecutive slides under $10 \times$ magnification. For the labial palp and mantle the infection intensity (macroscopic infection intensity, MII) was calculated under a dissecting microscope by counting the number of cysts ind. ${ }^{-1}$. All micrographs were captured using a Nikon DS-Fi1 video camera mounted on a Nikon 50i microscope connected to a computer. The images were shown on the monitor screen, and the number of cysts was obtained using the cell counter plug-in of Image $J$, a public domain imaging package (National Institutes of Health, USA: http://rsb.info.nih.gov/ij/). For the HID values, we established an arbitrary scale with the following 3 stages: (1) low intensity, values of $\leq 50$ cysts ind..$^{-1}$; (2) moderate intensity, values of 50 to 70 cysts ind. ${ }^{-1}$; (3) high intensity, values of $\geq 70$ cysts ind. $^{-1}$. Moreover, to obtain information regarding the host defence reaction against the parasite, the immune response efficiency (IRE) value was determined. This value was obtained by counting the number of capsules in which the metacercariae were dead from a total of 100 consecutive capsules and is reported as a percentage (\%). All other values are reported as the mean $\pm \mathrm{SD}$.
For morphological observations, the metacercarial cysts were scraped from the infected tissues and examined as wet mounts. A number of fixed specimens were stained with acetic carmine to highlight the developing organs. Measurements were obtained from 10 well-developed metacercariae using an Olympus BX41 microscope with a calibrated ocular micrometer. Drawings were made with the aid of a camera lucida. All measurements are expressed in micrometres $(\mu \mathrm{m})$.

Morphological analysis was performed according to the taxonomic keys of the family Monorchiidae (Hopkins 1941, Bray 2008a,b, Madhavi 2008) and the descriptions of species of the genus Postmonorchis (Hopkins 1941, Young 1953, Prudhoe \& Bray 1973).

\section{DNA amplification, sequencing and analysis}

Genomic DNA from the infected gills of 3 animals was extracted by Proteinase $\mathrm{K}$ digestion at $56^{\circ} \mathrm{C}$ for $16 \mathrm{~h}$ followed by phenol/chloroform/isoamyl alcohol extraction and ethanol precipitation. The DNA concentration was measured using a Nanodrop 2000c spectrophotometer (ThermoScientific), and the DNA quality was verified by electrophoresis on a $1 \%$ agarose gel stained with ethidium bromide. 
The ribosomal DNA (rDNA) region including the internal transcribed sequence 1 (ITS1), 5.8S and ITS2 was PCR amplified using the method of Bowles et al. (1995) and universal primers that anneal within the conserved $3^{\prime}$ terminus of the $18 \mathrm{~S}$ rDNA and the $5^{\prime}$ terminus of the 28S rDNA of Schistosoma species. The amplification mixture contained $10 \mathrm{ng}$ template DNA, $1 \times$ PCR buffer, $1.5 \mathrm{mM} \mathrm{MgCl}_{2}, 0.2 \mathrm{mM}$ of each deoxynucleotide, $0.4 \mu \mathrm{M}$ of each primer and 1.25 units of Taq DNA polymerase (Invitrogen) in a final volume of $40 \mu \mathrm{l}$. The amplification reaction was performed with an initial hot start at $95^{\circ} \mathrm{C}$ for 4 min followed by 35 cycles of $94^{\circ} \mathrm{C}$ for $1 \mathrm{~min}, 58^{\circ} \mathrm{C}$ for $1 \mathrm{~min}$ and $72^{\circ} \mathrm{C}$ for $1 \mathrm{~min}$, with a final extension step of $10 \mathrm{~min}$ at $72 \mathrm{C}^{\circ}$. The PCR products were run on $2 \%$ agarose gel.

The amplified fragments were gel eluted and cloned with the pGEM-T Easy Vector Cloning Kit (Promega) before being sequenced using the T7 and SP6 plasmid-specific universal primers and nested primers specific for the rDNA of Schistosoma (Bowles et al. 1995). The sequencing reactions were run on a 310 Automated Sequencer (Applied Biosystems).

The nucleotide sequences of ITS1 and/or ITS2 from different Trematoda species were downloaded from GenBank (see Table 2) and aligned with the corresponding region of the sequence obtained in this study. Based on the ITS1 and ITS2 alignments, the maximum likelihood trees were separately constructed using the MEGA5 program (Tamura et al. 2011). Bootstrap analysis was conducted on 1000 replicates.

\section{RESULTS}

\section{Gross and microscopic observation}

The prevalence of infection, macroscopical and histological infection intensity, and immune response efficiency values observed in the examined areas are reported in Table 1.
Macroscopically, the cysts appeared as whitish pearl-like formations in the organs and tissues of infected clams, such as the mantle, labial palps and gills (Fig. 2). In the gills, the cysts were distributed across the upper, middle and lower part of filaments and were usually aligned in a rosary-like pattern (Fig. 2D). Light microscopy also showed a high occurrence of the pathogen in the gill filaments in addition to the labial palps and mantle but not in the siphons. Moreover, in $10 \%$ of samples from the Volturno River mouth (2009), parasites were detected in the foot, the stomach and the kidney-pericardium system in cases of severe infection. Within the gills, the encysted metacercariae were located at the haemal sinus and at the connective tissue of the branchial axis. The cysts revealed a hyaline PAS-positive wall. The structure was rounded and consisted of a single layer approximately $2 \mu \mathrm{m}$ thick (Fig. 3A).

Histopathology revealed different features of the inflammatory response of the host (Fig. 3B,C). Depending on the case, the presence of metacercarial cysts was associated with a moderate/strong immune reaction characterised by an encapsulation-type response (De Vico \& Carella 2012a). Specifically, in cases of mild infection, the capsules comprised a monolayer of flattened immune cells around the cyst. In some cases $(13 \%)$ of severe infection $(154 \pm 1.2$ to $186 \pm 2.4)$, the inflammatory response was characterised by either a focal or diffuse haemocyte infiltration followed by the formation of multiple, large multi-layered capsules associated with tissue destruction. In some cases, parasite encapsulation resulted in rupture of the cyst wall, haemocyte invasion of the cyst and, finally, pathogen destruction. Notably, the early phases of pathogen development were sometimes histologically discernible. The pathogen was smaller $(\sim 200 \mu \mathrm{m})$ and had a thinner cyst wall with respect to the other metacercariae. In $10 \%$ of the cases, the pathogen appeared to be more susceptible to the host inflammatory response (Fig. 3F).

Table 1. Prevalence (P), mean \pm SD histological infection density (HID) at the gill and macroscopic infection intensity (MII) at mantle and labial palp, along with immune response efficiency (IRE) of the parasite infecting Donax trunculus from all sampled populations. n: number of specimens analysed; nc: not counted

\begin{tabular}{|c|c|c|c|c|c|c|c|c|}
\hline Areas & $\mathrm{n}$ & $\begin{array}{c}\text { Date of } \\
\text { collection }\end{array}$ & $\begin{array}{l}\text { Mean shell } \\
\text { length }(\mathrm{cm})\end{array}$ & $\mathrm{P}(\%)$ & HID gill & MII mantle & $\begin{array}{l}\text { MII labial } \\
\text { palp }\end{array}$ & IRE $(\%)$ \\
\hline Volturno River Mouth & 20 & July 2009 & 2.1 & 100 & $99 \pm 43.1$ & $4.8 \pm 1.7$ & $5 \pm 1.9$ & 6 \\
\hline Volturno River Mouth & 20 & July 2010 & 2.4 & 100 & $109 \pm 5.2$ & $3.2 \pm 2.2$ & $4 \pm 0.2$ & 7 \\
\hline Litorale Domitio & 20 & July 2012 & 2.7 & 100 & $50.8 \pm 1.2$ & $4.3 \pm 01$ & $5.4 \pm 0.2$ & 4 \\
\hline Formia & 20 & July 2012 & 2.5 & 85 & $45 \pm 10.2$ & $4 \pm 0.3$ & $3 \pm 0.1$ & 3 \\
\hline Tirrenia & 100 & June 2012 & 2.4 & 75.2 & $3.8 \pm 2.2$ & $\mathrm{nc}$ & nc & 0 \\
\hline Feraxi & 30 & September 2012 & 1.9 & 0 & - & - & - & - \\
\hline
\end{tabular}




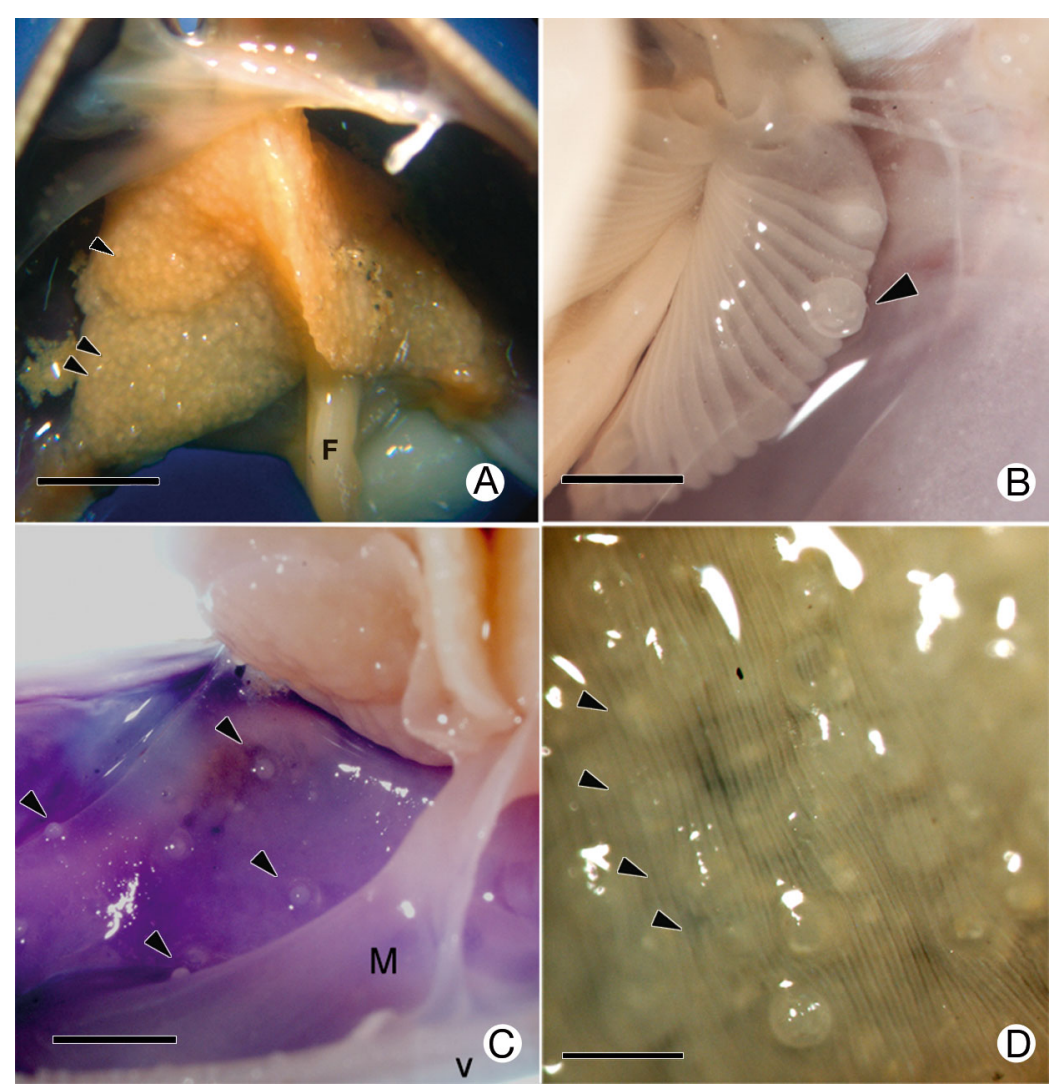

Fig. 2. Donax trunculus. Macroscopic views of clams infected with Postmonorchis sp. metacercariae. (A) Severe infestation of the gill (arrowheads) in clams from the Volturno River mouth. (B-D) Metacercaria at the labial palp (B), mantle (C) and gill (D) level. F: foot; V: valve; M: mantle. Scale bars = (A) $5 \mathrm{~mm}$, (B,D) $600 \mu \mathrm{m},(\mathrm{C}) 3 \mathrm{~mm}$

Other histopathogical findings included mild hypertrophy or hyperplasia of mucous cells and the connective tissue of the gills as demonstrated by PAS-BA and Trichrome staining, respectively (Fig. 3A,F). The encysted digenean metacercariae were always observed at a high prevalence in the clams (75 to $100 \%$ ), whereas the infection intensity values fluctuated among the geographical areas. The only exception was the set of samples from Feraxi (Sardinia), which were all negative (Table 1). The HID values were the highest at the Volturno River mouth 2009/2010, and ranged from 35 to 224 cysts ind. $^{-1}$ in 2009 and from 58 to 206 cysts ind. $^{-1}$ in 2010. In only a small percentage of the cases did parasite encapsulation resulted in pathogen destruction, with a low immune response efficiency value and a maximum of $8 \%$ destroyed cysts in severe infections. In clams from the other geographical areas and years, the histological infection intensity was lower, with minimal values recorded at Tirrenia $(3.80 \pm 2.21)$ and no IRE values (Table 1).

\section{Morphological description of the parasite}

Gill wet mounts from the infected clams showed the presence of a large number of round cysts of digenean metacercariae (Fig. 2) that were ascribed to Postmonorchis sp. inq.

Detailed analysis revealed spherical cysts with a diameter of 270 to $350 \mu \mathrm{m}$ (mean $326 \mu \mathrm{m}$ ) that were transparent and thin-walled so that the eyespots and vitellaria were clearly visible. The early stages of development were also observed. The early cysts were smaller $(180-220 \mu \mathrm{m})$ and more thin-walled compared to the older metacercariae, and the worms inside the cysts showed fewer, less distinct characters. Only the spined tegument, compact eyespots, oral and ventral sucker, and a thick-walled excretory bladder were discernible. Therefore, only well-developed metacercariae were used for the morphological description.

A description of the excysted worms, based on 10 specimens, is as follows (Fig. 4): the body is pyriform and elongated and measured 660-710 $\mu \mathrm{m}$ (mean $655 \mu \mathrm{m}$ ) long and 232-310 $\mu \mathrm{m}$ $(252 \mu \mathrm{m})$ wide. The tegument is entirely covered with minute spines, and there are eyespots at the level of the pharynx. The oral sucker is terminal, large and vase-shaped, 130-190 $\mu \mathrm{m}$ $(153 \mu \mathrm{m}) \times 112-132 \mu \mathrm{m}(124 \mu \mathrm{m})$. The prepharynx is short. The pharynx is elongated, $72-92 \mu \mathrm{m}(83 \mu \mathrm{m}) \times$ $52-58 \mu \mathrm{m}(55 \mu \mathrm{m})$. An oesophagus is present. There is intestinal bifurcation anterior to the genital opening. The caeca are long and reach posteriorly to the excretory bladder. The ventral sucker is round to oval, postequatorial, $63-88 \mu \mathrm{m}(71 \mu \mathrm{m}) \times 73-102 \mu \mathrm{m}$ $(81 \mu \mathrm{m})$. The testis is single, close to the posterior extremity, wider than it is long, and oval or reniform, 78-120 $\mu \mathrm{m}(104 \mu \mathrm{m}) \times 106-198 \mu \mathrm{m}(159 \mu \mathrm{m})$. The cirrus-sac is dextral and ' $<$ '-shaped, it extends posteriorly to the level of the ovarian hind margin, 181-280 $\mu \mathrm{m}$ $(218 \mu \mathrm{m}) \times 54-88 \mu \mathrm{m}(69 \mu \mathrm{m})$. The ovary is dextral, compact and adjacent to the testis, 38-72 $\mu \mathrm{m}(47 \mu \mathrm{m})$ $\times 30-75 \mu \mathrm{m}(56 \mu \mathrm{m})$. The metraterm is sinistral and bipartite, $135-155 \mu \mathrm{m}(146 \mu \mathrm{m}) \times 58-67 \mu \mathrm{m}(62 \mu \mathrm{m})$, including a short posterior saccular portion and a terminal portion. The common genital pore is median and is located between the intestinal bifurcation and the 


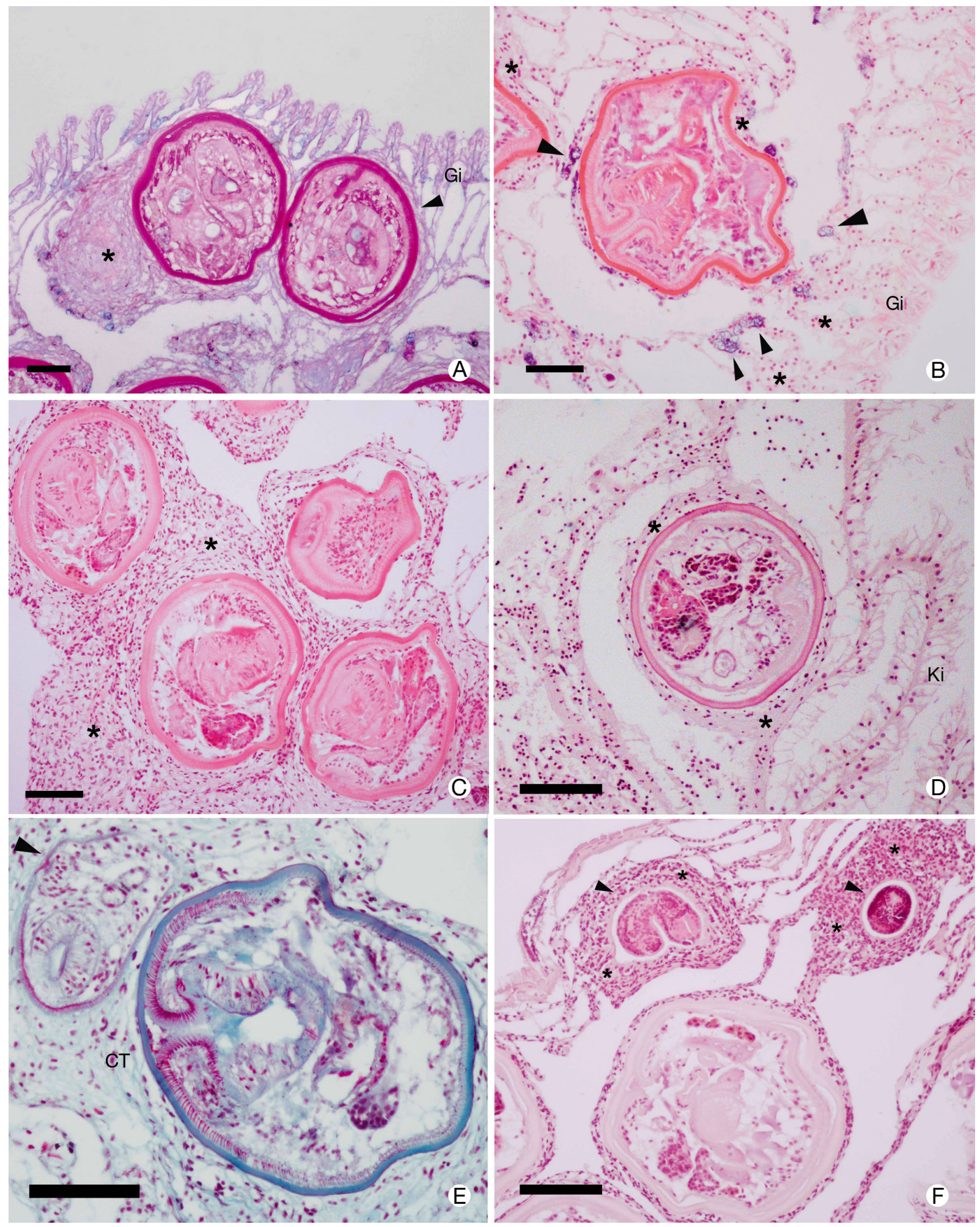

Fig. 3. Donax trunculus. Histopathology of wedge clam infected by Postmonorchis sp. (A) Parasites infecting the gills (Gi) show PAS-positive cysts; note the efficient capsule; PAS-BA staining. (B) Light inflammatory response accompanied by light mucous cell hypertrophy/hyperplasia (arrowheads); H\&E staining. (C) Heavy inflammatory response; H\&E staining. (D) Metacercariae located at the kidney (Ki) epithelium; H\&E staining. (E) Connective tissue (CT) hypertrophy as demonstrated by MassonTrichrome staining. (F) Heavy defence response against parasites at the early phase of development (arrowheads). Asterisks: haemocytes. Scale bars $=100 \mu \mathrm{m}$ 


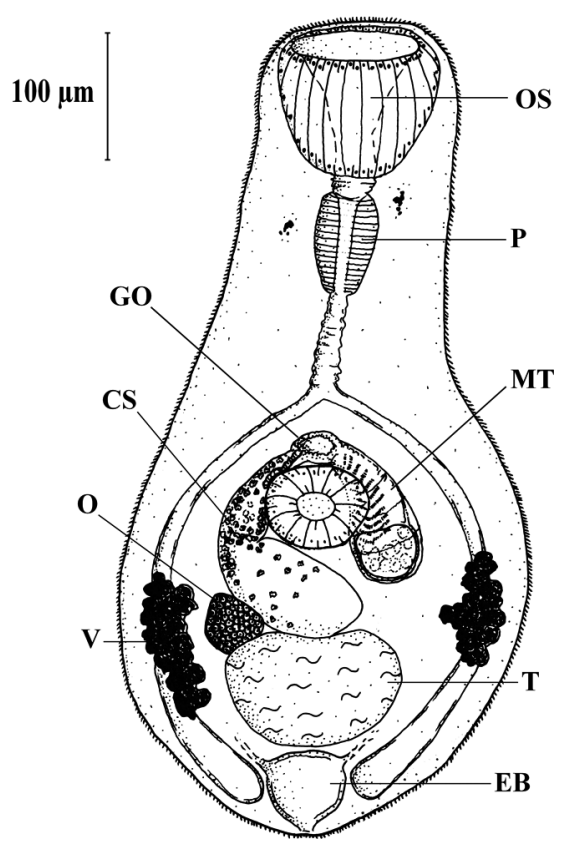

Fig. 4. Postmonorchis sp. Morphology of excysted metacercaria infecting the wedge clam Donax trunculus. CS: cirrus sac; EB: excretory bladder; GO: genital opening; MT: metraterm; O: ovary; OS: oral sucker; P: pharynx; T: testis; $\mathrm{V}$ : vitellaria

ventral sucker. The vitellarium consists of 2 lateral bunches of follicles at the level of the testis and ovary, each bunch measuring 48-91 $\mu \mathrm{m}(71 \mu \mathrm{m}) \times 30-58 \mu \mathrm{m}$ $(42 \mu \mathrm{m})$. The excretory bladder is small and globular, and the pore is terminal.

\section{Molecular phylogenetic analysis}

PCR amplification produced a $1105 \mathrm{bp}$ fragment, and BLAST analysis revealed that the sequenced fragment (deposited in GenBank under accession KC603478) corresponds to the expected region including the 3 '-terminus of the $18 \mathrm{~S}$ rDNA (44 bp), ITS1 (532 bp), 5.8S rDNA (159 bp), ITS2 (292 bp) and the $5^{\prime}$-terminus of the 28S rDNA (78 bp). The best nucleotide identity score $(\sim 70 \%)$ for the complete region was found for Aptorchis megapharynx (Plagiorchiidae), and the nucleotide alignment contained many indels $(>10 \%)$. Excluding the sequences corresponding to the $18 \mathrm{~S}, 5.8 \mathrm{~S}$ and $28 \mathrm{~S}$ rDNAs, the best nucleotide identity score was obtained for Monorchis monorchis (Monorchiidae) for ITS1 (83\%) and for Allobacciger centropygis (Monorchiidae) for ITS2 (87\%).

The nucleotide sequences of ITS1 and ITS2 obtained in this study were separately aligned with the corresponding region of Trematoda species in GenBank (Table 2). Unfortunately, within the Monorchiidae, the ITS1 sequences are known only for species belonging to the genus Monorchis, and the ITS2 sequences only for the genera Allobacciger and Hurleytrematoides. Fig. 5 shows the ITS1 and ITS2 trees obtained from the maximum likelihood analysis of the respective nucleotide alignments using Homalometron manteri as the outgroup taxon. In both the ITS1 and ITS2 trees, the Monorchiidae form a statistically supported group with a bootstrap value of $100 \%$, including the sequence obtained in the present study.

\section{DISCUSSION}

\section{Morphological and molecular data}

In this study, morphological observations combined with molecular analysis indicate that the observed

Table 2. Species, taxonomic position and GenBank accession numbers of the sequences used to construct the maximum likelihood trees. ${ }^{*}$ Sequence obtained in the present study

\begin{tabular}{|llcc|}
\hline Species & Taxonomy (all Digenea; Plagiorchiida) & Description & Accession number \\
\hline Aptorchis megapharynx & Plagiorchiata; Plagiorchioidea; Plagiorchiidae & ITS1 and ITS2 & EF014727 \\
Macroderoides trilobatus & Plagiorchiata; Plagiorchioidea; Macroderoididae & ITS1 and ITS2 & EU850410 \\
Renifer aniarum & Plagiorchiata; Plagiorchioidea; Reniferidae & ITS1 and ITS2 & HQ665460 \\
Telorchis bonnerensis & Plagiorchiata; Plagiorchioidea; Telorchiidae & ITS1 and ITS2 & JF820593 \\
Allobacciger centropygis & Monorchiata; Monorchiidae & ITS2 & JN969511 \\
Hurleytrematoides sp. & Monorchiata; Monorchiidae & ITS2 & JN969577 \\
Monorchis monorchis & Monorchiata; Monorchiidae & ITS1 & Y18939 \\
Monorchis parvus & Monorchiata; Monorchiidae & ITS1 & Y18935 \\
Monorchis sp. & Monorchiata; Monorchiidae & ITS1 & AJ277375 \\
Postmonorchis sp. inq. & Monorchiata; Monorchiidae & ITS1 and ITS2 & KC603478* \\
Homalometron manteri & Allocreadiata; Allocreadioidea; Apocreadiidae & ITS1 and ITS2 & JX400857 \\
\hline
\end{tabular}



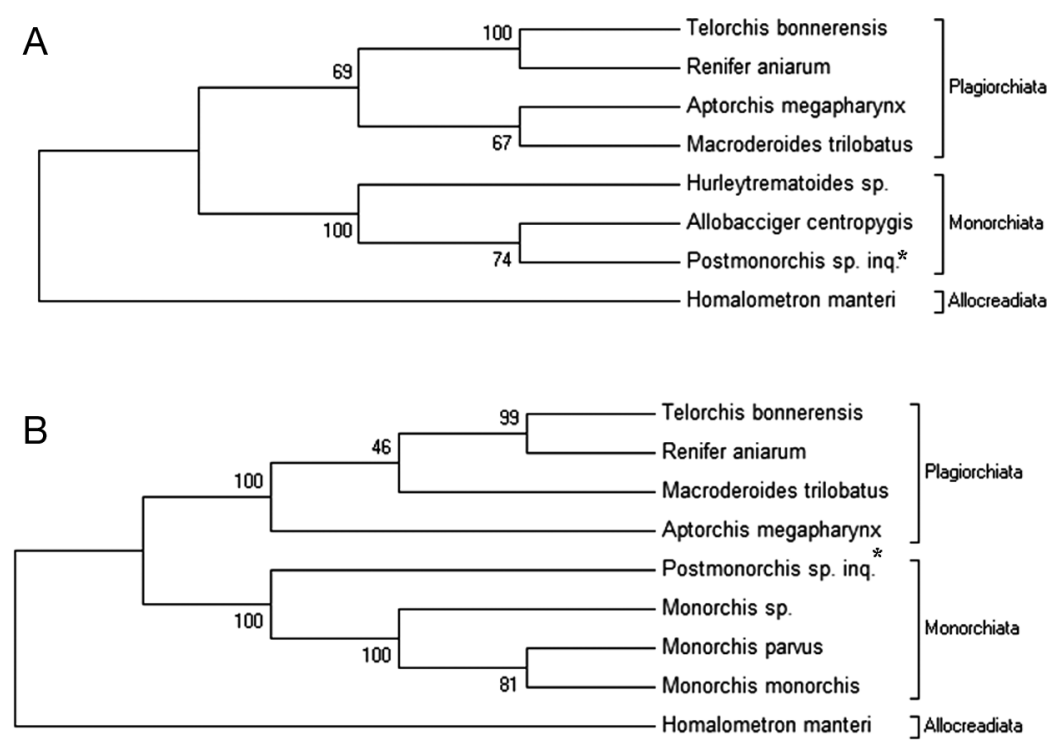

Fig. 5. Maximum likelihood trees of the (A) ITS1 and (B) ITS2 sequences. The numbers indicate the bootstrap percentage values. ${ }^{*}$ Sequence obtained in the present work

parasite that infects the wedge clam Donax trunculus belongs to the Monorchiidae, genus Postmonorchis.

In particular, morphological examination of the metacercariae assigned the parasite to the family Monorchiidae Odhner, 1911 according to Bray $(2008 \mathrm{a}, \mathrm{b})$ and to the genus Postmonorchis Hopkins, 1941 following the classification keys proposed by Hopkins (1941) and Madhavi (2008), except regarding the synonymisation determined by Madhavi (2008) of Alloproctotrema Machida, 1973 with Postmonorchis (Machida 1973, 2011). The most discriminating morphological feature of the genus Postmonorchis is the position of the vitellarium, which is situated at the same level as the testis and ovary, whereas in the related genera Monorchis Monticelli, 1893 and Telolecithus Lloyd \& Guberlet, 1932, the vitellarium is situated at the level of the pharynx and behind the testis, respectively. In Genolopa Linton, 1910, the vitellarium is at the same level as the testis, but the latter is located in the middle third of the body, whereas in Postmonorchis, the testis is near the posterior end. The genus Postmonorchis was established for the type species P. orthopristis Hopkins, 1941. Adults of this species occur in the gut of Haemulidae and Sciaenidae (Teleostea) from the US Atlantic coast (North Carolina), and its life cycle remains unknown. Young (1953) described another species, $P$. donacis, from the Pacific coast of the US. He found the adult worms in Sciaenidae and Embiotocidae (Teleostei) but also found parthenitae, cercariae and metacercariae in the bean clam Donax gouldii. Fur- ther similar observations by Winter \& Hatch (2010) support a 2-host life history model for $P$. donacis, which can use $D$. gouldii as both a primary and a secondary host, rather than a 3-host model with a copepod as the primary host (Young 1953). The third species belonging to this genus is $P$. variabilis Prudhoe \& Bray, 1973 which is found in Nototheniidae and Harpagiferidae (Teleostei) from sub-Antarctic waters, as reported by Zdzitowiecki (1991) and Rocka (2006). According to Madhavi (2008), the genus Alloproctotrema Machida, 1973 should be considered as a synonym of Postmonorchis, meaning that the type and only species of that genus, A. gerres Machida, 1973 is the fourth member of the genus. However, Machida (2011) redescribed A. gerres, stating (p. 1) that 'Alloproctotrema is valid, distinguishable from Postmonorchis by possessing an unarmed genital atrium and a unipartite terminal organ'.

Here, the metacercariae show a combination of features of the 3 above species but also display some unique characteristics not previously described. The metacercaria more closely resemble Postmonorchis orthopristis because of the following 3 features: first, the testis is reniform and is wider than it is long, while in $P$. donacis the opposite is true and in $P$. variabilis it is globular; second, the body is fully covered with spines, rather than only being covered to the acetabulum, as was reported by Young (1953) for both the larval and adult stages of $P$. donacis; and third, the posterior portion of the metraterm is short, which is very different from the elongated metraterm of $P$. variabilis, as described by Prudhoe \& Bray (1973). In contrast, the short, globular, excretory bladder appears identical to that of $P$. donacis, whereas the excretory bladder of $P$. orthopristis is Ishaped and reaches the anterior margin of the testis, while $P$. variabilis shows both forms. For our specimen, other features, such as the shape of the body, appear to be intermediate.

However, a very distinctive characteristic of our metacercaria, observed in Postmonorchis for the first time here, is the vase or funnel shape of the terminal oral sucker, which is similar to other Monorchiidae, such as Genolopa beauforti Hopkins, 1941.

In our case, the molecular analysis confirms that the parasite belongs to the Monorchiidae family, although it is not Monorchis, Allobacciger or Hurley- 
trematoides. This finding strongly supports the hypothesis, based on the above morphological data, that this is the first record for a species of Postmonorchis in the Mediterranean Sea.

\section{Host-parasite interaction}

In the current study, the inflammatory response was the most relevant lesion. In particular, the encapsulation-type response is a common immune defence reaction towards foreign bodies, such as multicellular parasites, which enter the haemocoel and are too large to be phagocytosed. This reaction comprises a complex multistep process. It consists of a recognition phase, mediated by the coordinated interaction of immunocytes with the parasite surface and its secreted products, and a phase consisting of a response by cooperating activated haemocytes to form multicellular capsules against the foreign body by adhering to and enclosing it. The cytotoxic products are then released by haemocyte degranulation to destroy the invader (De Vico \& Carella 2012a,b). In the present case, the latter step was often ineffective, and the parasite was eliminated in only a few cases.

Taken together, the above morphological and molecular data suggest that a new species of the genus Postmonorchis affects Donax trunculus of the Tyrrhenian coast of the Mediterranean Sea. Further studies accompanied by molecular analysis are necessary to fully elucidate the parasite rDNA sequence and life cycle. The specific differentiation of metacercariae is often difficult because factors such as the lack of distinctive morphological characteristics in larvae make their association with adults very problematic. To fill this gap, attempts at experimental infections and parasitological studies focused on key areas would permit the observation of the early larval stages and adults of Postmonorchis sp. inq. in the first intermediate and definitive hosts, respectively. In particular, the adult stages may more likely occur in Sciaenidae, of which some species are preferred definitive hosts for $P$. orthopristis and P. donacis (Hopkins 1941, Young 1953, Winter \& Hatch 2010). This is because Looss (1907) established (unfortunately without an adequate description) the new monorchid genus and species Pristisomum caducum Looss, 1907 infecting the scienid Umbrina cirrhosa, and Yamaguti (1958) synonymised this genus with Postmonorchis. Since to date this species has not been observed again, it would be very important to find adult monorchids in $U$. cir- rhosa from Italian waters, and compare them with our metacercariae both morphologically and molecularly, in order to assess their identity.

With regard to molecular analysis, rDNA sequences clearly distinguish the different trematode species, including combinations for which morphology gives ambiguous results. At present, no sequences from the genus Postmonorchis other than those presented here are available in GenBank, with most information provided for the Monorchiidae rRNA 18S and $28 \mathrm{~S}$ regions. Further ongoing research is focused on better characterising the molecular data of other existing Postmonorchis species and related genera, collecting additional baseline data regarding infection by this Postmonorchis sp. inq. in Donax trunculus in the Mediterranean Sea and assessing the impact of these pathogens on the wedge clam stock population.

Acknowledgements. We thank G. Villari for technical support and R. A. Bray for providing the description of Postmonorchis variabilis.

\section{LITERATURE CITED}

Bartoli P (1983) The larval stages of Meiogymnophallus strigatus (MV Lebour 1908) n. comb. (Trematoda: Gymnophallidae). Ann Parasitol Hum Comp 58:227-242

Bartoli P (1984) Distomatoses des lamellibranches marins sur le littoral méditerranéen Français. Haliotis 14:98-107

Bartoli P, Jousson O, Russell-Pinto E (2000) The life-cycle of Monorchis parvus (Digenea: Monorchiidae) demonstrated by developmental and molecular data. J Parasitol 86:479-489

Berthe FCJ (2008) New approaches to effective mollusc health management. In: Bondad-Reantaso MG, Mohan CV, Crumlish M, Subasinghe RP (eds) Diseases in Asian aquaculture VI. Fish Health Section, Asian Fisheries Society, Manila, p 343-352

$>$ Bowles J, Blair D, Mc Manus DP (1995) A molecular phylogeny of the human schistosomes. Mol Phylogenet Evol 4:103-109

Bray RA (2008a) Introduction and key to superfamilies. In: Bray RA, Gibson DI, Jones A (eds) Keys to the Trematoda, Vol 3. CAB International and Natural History Museum, London, p 1-5

Bray RA (2008b) Superfamily Monorchioidea Odhner 1911. In: Bray RA, Gibson DI, Jones A (eds) Keys to the Trematoda Vol 3. CAB International and Natural History Museum, London, p 143-144

Bush AO, Lafferty KD, Lotz JM, Shostak AW (1997) Parasitology meets ecology on its own terms: Margolis et al. revisited. J Parasitol 83:575-583

Comps M (1979) A rickettsial microorganism in the mollusc Donax trunculus L. Rapp P-V Reun Comm Int Explor Mer Mediterr 25/26:35-36

Cribb TH, Bray RA, Olson PD, Littlewood DTJ (2003) Life cycle evolution in the Digenea: a new perspective from phylogeny. Adv Parasitol 54:197-254 
Culurgioni J, D'Amico V, De Murtas R, Canestri-Trotti G, Figus V (2006) Parasitological monitoring of commercial native bivalves from St. Gilla lagoon (Sardinia, South Western Mediterranean). Ittiopatologia 3:243-252

- De Montaudouin X, Thieltges DW, Gam M, Krakau M and others (2009) Digenean trematode species in the cockle Cerastoderma edule: identification key and distribution along the north-eastern Atlantic shoreline. J Mar Biol Assoc UK 89:543-556

$>$ De Vico G, Carella F (2012a) Morphological features of the inflammatory response in molluscs. Res Vet Sci 93: 1109-1115

De Vico G, Carella F (2012b) Eziologia. In: De Vico G, Carella $F$ (eds) Argomenti di patologia comparata dei molluschi: aspetti ecologici e sanitari. Loffredo, Naples, p 58-78

Doanh PN, Shinohara A, Horii Y, Habe S, Nawa Y, The DT, Le NT (2007) Morphological and molecular identification of two Paragonimus spp., of which metacercariae concurrently found in a land crab, Potamiscus tannanti, collected in Yenbai Province, Vietnam. Parasitol Res 100: 1075-1082

Fishelson L, Bressler V, Manelis R, Zuk-Rimon Z, Dotan A, Yawetz A (1999) Toxicological aspects associated with the ecology of Donax trunculus (Bivalvia, Mollusca) in a polluted environment. Sci Total Environ 226:121-131

- Gaspar MB, Chícharo LM, Vasconcelos P, Garcia A, Santos AR, Monteiro CC (2002) Depth segregation phenomenon in Donax trunculus (Bivalvia: Donacidae) populations of the Algarve coast (southern Portugal). Sci Mar 66: 111-121

Hopkins SH (1941) New genera and species of the family Monorchiidae (Trematoda) with the discussion of the excretory system. J Parasitol 27:395-407

La Valle P (2006) Donax trunculus (Bivalvia: Donacidae) quale indicatore biologico degli equilibri costieri e del bilancio sedimentario. PhD dissertation, University of Rome

Lauckner G (1983) Diseases of Mollusca: Bivalvia. In: Kinne O (ed) Diseases of marine animals, Vol 2: Introduction, Bivalvia to Scaphopoda. Biologische Anstalt Helgoland, Hamburg, p 632-750

Looss A (1907) Zur Kenntnis der Distomenfamilie Hemiuridae. Zool Anz 31:585-620

Machida M (1973) Two new trematodes from the gerrid fish of Bungo Channel, Japan. Bull Nat Sci Mus 16: 429-435

Machida M (2011) Additional monorchiid digeneans (Trematoda) from fishes of Japanese and adjacent waters. Bull Natl Mus Nat Sci Ser A 37:1-8

Madhavi R (2008) Family Monorchiidae. In: Bray RA, Gibson DI, Jones A (eds) Keys to the Trematoda, Vol 3. CAB

Editorial responsibility: David Marcogliese,

Montreal, Quebec, Canada
International and Natural History Museum, London, p 145-175

Maillard C (1975) Cycle evolutif de Paratimonia gobii Prevot et Bartoli, 1967 (Trematoda-Monorchiidae). Acta Trop 32:327-339

Manca Zeichen M, Agnesi S, Mariani A, Maccaroni A, Ardizzone GD (2002) Biology and population dynamics of Donax trunculus L. (Bivalvia: Donacidae) in the South Adriatic coast (Italy). Estuar Coast Shelf Sci 54:971-982

Martin WE (1940) Studies on the trematodes of Woods Hole III. Life cycle of Monorcheides cumingiae (Martin) with special reference to its effect on invertebrate host. Biol Bull (Woods Hole) 79:131-144

Mazzi V (1977) Manuale di tecniche istologiche e istochimiche. Piccin, Rome

Palombi A (1934) Gli stadi larvali dei Trematodi del Golfo di Napoli. Pubbl Staz Biol Napoli 14:51-94

Prudhoe S, Bray RA (1973) Digenetic trematodes from fishes. BANZ Antarct Res Exped Rep Ser B (Zool Bot) 8: 195-225

Ramòn M, Gracenea M, Gonzales-Moreno O (1999) Bacciger bacciger (Trematoda, Fellodistomidae) infection in commercial clams Donax trunculus (Bivalvia, Donacidae) from the sandy beaches of the Western Mediterranean. Dis Aquat Org 35:37-46

Rocka A (2006) Helminths of Antarctic fishes: life cycle biology, specificity and geographical distribution. Acta Parasitol 51:26-35

Tamura K, Peterson D, Peterson N, Steker G, Nei M, Kumar S (2011) MEGA5: molecular evolutionary genetics analysis using maximum likelihood, evolutionary distance, and maximum parsimony methods. Mol Biol Evol 28: 2731-2739

Winter RN, Hatch MBA (2010) Investigating the parasitism of southern California bean clams (Donax gouldii) by the trematode Postmonorchis donacis. Bull South Calif Acad Sci 109:144-152

Yamaguti S (1958) Systema Helminthum, Vol I Parts I-II. The digenetic trematodes of vertebrates. Interscience Publishers, New York, NY

Yawetz A, Fishelson L, Bresler V, Manelis R (2010) Comparison of the effects of pollution on the marine bivalve Donax trunculus in the vicinity of polluted sites with specimens from a clean reference site (Mediterranean Sea). Mar Pollut Bull 60:225-229

Young RT (1953) Postmonorchis donacis, a new species of monorchid trematode from the Pacific coast, and its life history. J Wash Acad Sci 43:88-93

Zdzitowiecki K (1991) Occurrence of digeneans in open sea fishes off the South Shetland Islands and South Georgia, and a list of fish digeneans in the Antarctic. Pol Polar Res $12: 55-72$

Submitted: April 11, 2013; Accepted: July 10, 2013

Proofs received from author(s): September 19, 2013 